\begin{tabular}{|c|c|c|}
\hline & $\begin{array}{c}\text { JOURNAL } \\
\text { PENELITIAN PENDIDIKAN IPA }\end{array}$ & $\begin{array}{l}e-I S S N: 2407-795 X \\
p-I S S N: 2460-2582\end{array}$ \\
\hline WPIPA Is & $\underline{\text { http://jurnal.unram.ac.id/index.php/jpp-ipa }}$ & $\begin{array}{l}\text { Vol 1, No, } 2 \\
\text { Juli } 2015\end{array}$ \\
\hline
\end{tabular}

\title{
PENGARUH EKSTRAK ETANOL DAUN JAMBU AIR (SYZYGIUM AQUEUM) TERHADAP BAKTERI ISOLAT KLINIS
}

\author{
Titi Hariyati $^{1}$, Dwi Soelistya Dyah Jekti ${ }^{2}$, Yayuk Andayani ${ }^{2}$ \\ Program Studi Magister Pendidikan IPA Program Pascasarjana Universitas Mataram ${ }^{123}$ \\ titihariyati99@yahoo.com
}

\begin{tabular}{|c|c|}
\hline Key Words & Abstract \\
\hline $\begin{array}{l}\text { Antibacteria, } \\
\text { Guava Leaf, } \\
\text { Clinical Isolates } \\
\text { Bacteria, } \\
\text { Ethanol Extract }\end{array}$ & $\begin{array}{l}\text { Syzygium aqueum plant of the family Myrtaceae is native of Malaysia and Indonesia } \\
\text { and is known as the water rose. The active compound is useful as an antibacterial. } \\
\text { This study aimed to determine the effects of ethanol extracts of guava leaves (S. } \\
\text { aqueum) as an antimicrobial against clinical isolates bacteria in vitro. The design } \\
\text { used in experiment was a Completely Randomized Design (CRD). Data were analyzed } \\
\text { using the Kruskal-Wallis test. Results of statistical analysis using SPSS } 20 \text { for } \\
\text { windows indicated that the ethanol extract of guava leaves has a significant (P<0,05) } \\
\text { effect in inhibiting the growth of clinical isolates bacteria. MIC (Minimum Inhibition } \\
\text { Concentration) of ethanol extracts for each bacterium can not be determined because } \\
\text { the guava leaf extract was very dark. The MBC (Minimum Bacterisidal } \\
\text { Concentration) of ethanol extract of guava leaf for both S. aureus and S. dysenteriae } \\
\text { was } 20 \% \text {. The MBC of the extract for E. coli, S. thypi, V. cholerae was } 25 \% \text {, where as } \\
\text { for B. cereus was at concentration of 50\%. It can be concluded that guava leaf has } \\
\text { highly potential as a source of antimicrobial agent }\end{array}$ \\
\hline
\end{tabular}

\begin{tabular}{ll}
\hline Kata Kunci & Abstrak \\
\cline { 1 - 1 } $\begin{array}{l}\text { Antibakteri, } \\
\text { Daun Jambu }\end{array}$ & Syzygium aqueum dari famili Myrtaceae adalah tanaman asli Malaysia dan Indonesia \\
Air, Bakteri & pengaruh ekstrak etanol daun jambu air (Syzygium aqueum) sebagai antimikroba \\
Isolat Klinis, & terhadap bakteri isolat klinis secara in vitro. Disain penelitian ini Rancangan Acak \\
Ekstrak Etanol & Lengkap $($ RAL). Data yang diperoleh dianalisis dengan menggunakan uji Kruskal- \\
& Wallis dengan menggunakan program SPSS 20 for windows. Hasil menunjukkan \\
& bahwa ekstrak etanol daun jambu air berpengaruh secara signifikan $(P<0,05)$ dalam \\
& menghambat pertumbuhan bakteri isolat klinis. Konsentrasi Hambat Minimum (KHM) \\
& ekstrak etanol masing-masing bakteri tidak dapat ditentukan karena ekstrak daun \\
& jambu air berwarna gelap. Dari hasil analisis diketahui bahwa Konsentrasi Bunuh \\
& Minimum (KBM) ekstrak etanol pada bakteri S. aureus dan S. dysenteriae yaitu 20\%; \\
& E. coli, S. thypi, V. cholerae yaitu 25\%; B. cereus pada konsentrasi 50\%. Dapat \\
& disimpulkan bahwa daun jambu air memiliki potensial yang besar sebagai sumber \\
& antimikroba
\end{tabular}




\section{PENDAHULUAN}

Indonesia merupakan negara yang terkenal dengan keanekaragaman tanaman. Hal ini didukung oleh keadaan geografis Indonesia yang beriklim tropis dengan curah hujan rata-rata tinggi sepanjang tahun. Sumber daya alam yang dimiliki telah memberikan manfaat dalam kehidupan sehari-hari disamping sebagai bahan makanan dan bahan bangunan, juga dimanfaatkan sebagai obat tradisional (Parwata dan Dewi, 2008).

Jumlah tumbuhan berkhasiat obat di Indonesia diperkirakan sekitar 1.260 jenis tumbuhan. Tumbuhan menghasilkan metabolit sekunder yang berpotensi sebagai antioksidan, zat pewarna, penambah aroma makanan, parfum, dan obat (Indrayanto, 2006). Secara umum, khasiat tumbuhan obat sebenarnya terkait dengan kandungan kimia yang dimiliki. Namun, tidak seluruh kandungan kimia diketahui secara lengkap karena pemeriksaan bahan kimia dari suatu tanaman memerlukan biaya yang mahal. Meskipun tidak secara rinci, tetapi pendekatan farmakologi menghasilkan informasi tentang khasiat tumbuhan obat (Hariana, 2006). Tumbuhan umumnya mengandung senyawa aktif dalam bentuk metabolit sekunder seperti alkaloid, flavonoid, steroid, triterpenoid, kumarin (Indrayanto, 2006).

S. aqueum dari famili Myrtaceae adalah tanaman asli Malaysia dan Indonesia dan dikenal sebagai jambu air. Hasil penelitian Thamilvaani dkk., (2012) menyatakan bahwa ekstrak etanol daun S. aqueum mengandung enam jenis flavonoid yaitu 4hydroxybenzaldehyde, myricetin-3-O-rhamnoside, europetin-3-O-rhamnoside, phloretin, myrigalone-G dan myrigalone-B. Palanisamy dkk., (2011) menyatakan bahwa daun $S$. aqueum mengandung senyawa fenolik. Menurut Wong dan Lai (1996) genus Syzygium mengandung terpenoid dan $\gamma$ terpinene dalam jumlah yang tinggi. Tanin juga ditemukan dalam daun spesies S. aqueum (Okuda dkk., 1982). Daun jambu air mengandung acutissimin A, castalagin, casuarinin, eugenigrandin A, eugeniin, 4,6-hexahydroxydiphenoylglucose, grandinin, pedunculagin, 1-beta- O-galloylpedunculagin, vescalagin, epi-(-)-gallocatechin, epi-(-)-gallocatechin-3-O-gallate, prodelphinidin B-2 3,3-di-Ogallate (Okuda dkk., Nonaka G.I dkk., dalam WHO, 2009).

Dalam rangka meningkatkan daya guna salah satu sumber alam Indonesia yang sangat melimpah dan sekaligus sebagai usaha penyediaan senyawa antibakteri yang berkhasiat tinggi, relatif murah dan aman serta pencarian antibakteri baru yang dapat 
menyembuhkan penyakit yang disebabkan oleh bakteri patogen yang telah resisten, maka dalam penelitian ini akan mempelajari aktivitas antibakteri dari ekstrak etanol daun jambu air yang keberadaannya melimpah. Tujuan penelitian ini adalah untuk mengetahui pengaruh antibakteri, KHM, dan KBM ekstrak etanol daun jambu air terhadap bakteri isolat klinis.

\section{METODE PENELITIAN}

Jenis penelitian ini adalah penelitian eksperimental laboratorium. Rancangan percobaan yang digunakan adalah Rancangan Acak Lengkap (RAL) dengan tiga kali ulangan untuk masing-masing konsentrasi terhadap setiap bakteri uji. Digunakan enam jenis bakteri yaitu Bacillus cereus, Shigella dysenteriae, Staphylococcus aureus, Escherichia coli, Vibrio cholerae, Salmonella thypi yang disesuaikan dengan kekeruhan Mac Farland 0,5 setara 1,5 x $10^{8} \mathrm{CFU} / \mathrm{mL}$. Kontrol positif menggunakan ciprofloksasin dan kontrol negatif menggunakan aquades. Populasi penelitian ini adalah daun jambu air yang diperoleh dari satu pohon jambu air yang berlokasi di wilayah Ampenan. Sedangkan Sampel dalam penelitian ini adalah daun muda jambu air sebanyak 500 gram. Ekstraksi daun jambu air dengan metode maserasi menggunakan pelarut etanol. Pengujian besar daya hambat menggunakan metode sumur difusi yang hasilnya ditentukan berdasarkan kriteria Mukherjee (Tabel 1.)

Tabel 1. Kategori Zona Hambat Bakteri

\begin{tabular}{lll}
\hline No & Diameter Zona Hambat & Kategori \\
\hline 1. & Diameter $>12 \mathrm{~mm}$ & termasuk kategori Sensitif \\
2. & Diameter $4<\phi \leq 12 \mathrm{~mm}$ & termasuk kategori Intermediet \\
3. & Diameter $=4 \mathrm{~mm}$ & termasuk kategori Resisten \\
\hline
\end{tabular}

Uji KHM (Konsentrasi Hambat Minimum) yaitu konsentrasi terkecil yang mampu mengambat pertumbuhan bakteri isolat klinis menggunakan metode dilusi tabung dan uji KBM (Konsentrasi Bunuh Minimum) yaitu konsentrasi terendah yang mampu membunuh bakteri isolat klinis menggunakan metode cawan gores.

Ekstrak etanol daun jambu air terdiri dari konsentrasi 75\%, 50\%, 25\%, 20\%, 15\%, dan 10\%. Dari masing-masing konsentrasi tersebut diambil sebanyak $1 \mathrm{ml}$ lalu dimasukkan ke dalam tabung reaksi kemudian diberi label sesuai konsentrasi. Suspensi 
bakteri yang telah dipersiapkan sebelumnya diambil $1 \mathrm{ml}$ dimasukkan ke dalam masingmasing tabung yang telah diberi label kemudian divorteks hingga homogen. Selanjutnya tabung tersebut diinkubasi pada suhu $37^{\circ} \mathrm{C}$ selama 24 jam pada inkubator kemudian diamati kejernihannya. Larutan yang jernih dari larutan sampel berarti dapat menghambat pertumbuhan bakteri ditetapkan sebagai KHM. Penentuan KBM dilakukan dengan cara menggoreskan larutan dari KHM yang jernih pada media NA dan diinkubasi pada suhu $37^{\circ} \mathrm{C}$ selama 24 jam pada inkubator kemudian dilihat ada tidaknya pertumbuhan bakteri.

\section{HASIL DAN PEMBAHASAN}

Tabel 2. Data Hasil Pengukuran Zona Hambat Ekstrak Daun Jambu Air (Syzygium aqueum) dengan Pelarut Etanol

\begin{tabular}{|c|c|c|c|c|c|}
\hline \multirow{2}{*}{ Jenis Bakteri } & \multicolumn{5}{|c|}{ Ekstrak Etanol } \\
\hline & $25 \%$ & $50 \%$ & $75 \%$ & $\mathbf{K}+$ & K- \\
\hline Bacillus cereus & 19 & 24 & 29 & 20 & 0 \\
\hline Kategori & $\mathbf{S}$ & $\mathbf{S}$ & $\mathbf{S}$ & $\mathbf{S}$ & \\
\hline Escherichia coli & 17,67 & 27 & 36,67 & 21 & 0 \\
\hline Kategori & $\mathbf{S}$ & $\mathbf{S}$ & $\mathbf{S}$ & $\mathbf{S}$ & \\
\hline Staphylococcus aureus & 17,67 & 20,67 & 23 & 21 & 0 \\
\hline Kategori & $\mathbf{S}$ & $\mathbf{S}$ & $\mathbf{S}$ & $\mathbf{S}$ & \\
\hline Salmonella thypi & 21,33 & 25,33 & 36,67 & 21 & 0 \\
\hline Kategori & $\mathbf{S}$ & $\mathbf{S}$ & $\mathbf{S}$ & $\mathbf{S}$ & \\
\hline Shigella dysenteriae & 21,33 & 25 & 29 & 35 & 0 \\
\hline Kategori & $\mathbf{S}$ & $\mathbf{S}$ & $\mathbf{S}$ & $\mathbf{S}$ & \\
\hline Vibrio cholerae & 20,67 & 24,67 & 27,33 & 35 & 0 \\
\hline Kategori & $\mathbf{S}$ & $\mathbf{S}$ & $\mathbf{S}$ & $\mathbf{S}$ & \\
\hline
\end{tabular}

Keterangan: R=Resisten; I=Intermediet; $\mathrm{S}=$ Sensitif

Data Tabel 2. menunjukkan bahwa ekstrak etanol daun jambu air dalam konsentrasi 25\%, 50\%, dan 75\% mampu menghambat pertumbuhan bakteri isolat klinis dan keseluruhannya tergolong dalam kategori sensitif dan terlihat terjadi peningkatan besar daya hambat bakteri seiring dengan besarnya konsentrasi ekstrak. Hal ini berarti bahwa kandungan senyawa dalam ekstrak memiliki efek antimikroba.

Efek antibakteri ekstrak etanol daun jambu air (Syzygium aqueum) terhadap bakteri isolat klinis disebabkan oleh zat-zat aktif yang larut dalam etanol. Diperkirakan zat-zat yang terkandung dalam daun jambu air (Syzygium aqueum) yang larut dalam etanol adalah flavonoid, fenolik, dan tanin. Mekanisme kerja flavonoid sebagai antibakteri adalah membentuk senyawa kompleks dengan protein ekstraseluler dan terlarut sehingga dapat 
merusak membran sel bakteri yang diikuti dengan keluarnya senyawa intraseluler (Cowan, 1999; Nuria dkk., 2009; Bobbarala, 2012).

Menurut Singh dan Bharate (2005), senyawa fenol memiliki mekanisme kerja dalam menghambat pertumbuhan bakteri dengan cara inaktivasi protein (enzim) pada membran sel. Menurut Susanti (2008), fenol berikatan dengan protein melalui ikatan hidrogen sehingga mengakibatkan struktur protein menjadi rusak karena sebagian besar struktur dinding sel dan membran sitoplasma bakteri mengandung protein dan lemak. Ketidakstabilan pada dinding sel dan membran sitoplasma bakteri menyebabkan fungsi permeabilitas selektif, fungsi pengangkutan aktif, pengendalian susunan protein dari sel bakteri menjadi terganggu, yang akan berakibat pada lolosnya makromolekul, dan ion dari sel. Sehingga sel bakteri menjadi kehilangan bentuknya, dan terjadilah lisis.

Mekanisme kerja tanin sebagai antibakteri adalah mampu mengerutkan dinding sel bakteri sehingga dapat mengganggu permeabilitas sel. Terganggunya permeabilitas sel dapat menyebabkan sel tersebut tidak dapat melakukan aktifitas hidup sehingga pertumbuhannya terhambat dan karena pengerutan dinding sel bakteri sehingga bakteri mati (Maliana dkk., 2013). Menurut Sari dan Sari (2011), tanin mempunyai target pada polipeptida dinding sel sehingga pembentukan dinding sel menjadi kurang sempurna. Hal ini menyebabkan sel bakteri menjadi lisis karena tekanan osmotik maupun fisik sehingga sel bakteri akan mati.

Data hasil pengukuran diameter uji hambat ekstrak daun jambu air (Tabel 2) (Syzygium aqueum) dengan pelarut etanol kemudian dilakukan uji Kruskal-Wallis, hasil analisisnya disajikan pada Tabel 3:

Tabel 3. Hasil Analisis Uji Kruskal Wallis Ekstrak Etanol Daun Jambu Air (Syzygium aqueum)

\begin{tabular}{lcc}
\hline \multicolumn{1}{c}{ Bakteri } & Df & Assymp. Sig \\
\hline Bacillus cereus & 4 & .028 \\
Escherichia coli & 4 & .011 \\
Staphylococcus aureus & 4 & .015 \\
Salmonella thypi & 4 & .011 \\
Shigella dysenteriae & 4 & .008 \\
Vibrio cholera & 4 & .008 \\
\hline
\end{tabular}

Berdasarkan hasil analisis tersebut maka dapat dinyatakan bahwa ekstrak etanol daun jambu air (Syzygium aqueum) memberikan pengaruh yang sangat nyata $(\mathrm{P}<0,05)$ 
terhadap pertumbuhan berbagai bakteri isolat klinis dengan terbentuknya zona hambat di sekitar sumur yang berisi ekstrak etanol daun jambu air (Syzygium aqueum).

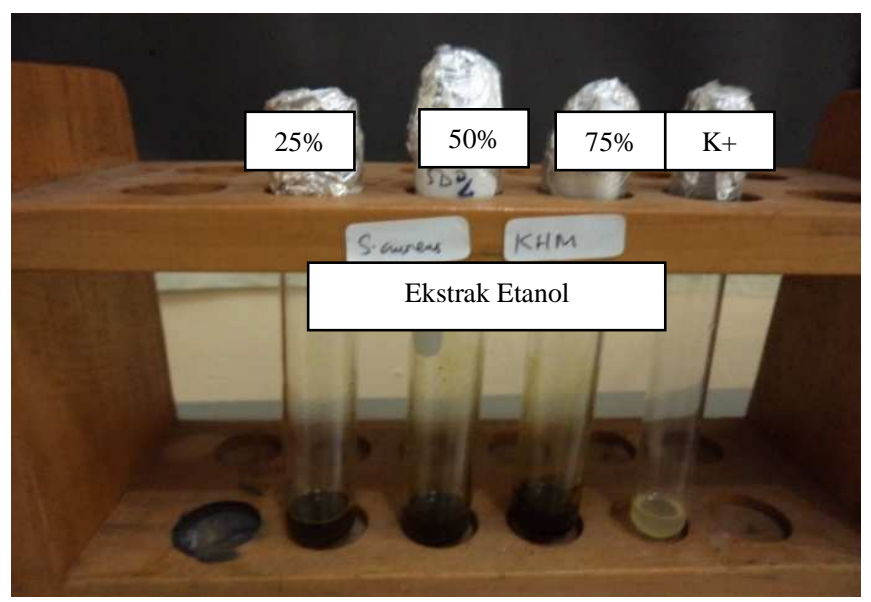

Gambar 1. Tingkat Kejernihan Masing-masing Konsentrasi Ekstrak Etanol Daun Jambu Air (Syzygium aqueum)

Berdasarkan Gambar 1 dapat dijelaskan bahwa semua konsentrasi menunjukkan warna yang gelap. Akibat warna yang gelap tersebut, maka Kadar Hambat Minimal (KHM) ekstrak etanol daun jambu air (Syzygium aqueum) terhadap bakteri isolat klinis ini tidak dapat diamati. Selanjutnya larutan yang ditetapkan sebagai KHM tersebut selanjutnya dikultur ulang pada media padat tanpa penambahan ekstrak daun jambu air, dan diinkubasi selama 18-24 jam. Jika tidak ada pertumbuhan bakteri ditetapkan sebagai Kadar Bunuh Minimal (KBM) dan hasilnya disajikan pada Tabel 4 di bawah ini:

Tabel 4. Hasil Uji Konsentrasi Bunuh Minimum Ekstrak Etanol Daun Jambu Air (Syzygium aqueum)

\begin{tabular}{|c|c|c|c|c|c|c|c|c|}
\hline \multirow[t]{2}{*}{ Bakteri } & \multicolumn{8}{|c|}{ Konsentrasi (\%) } \\
\hline & 10 & 15 & 20 & 25 & 50 & 75 & K- & K+ \\
\hline Bacillus cereus & + & + & + & + & - & - & + & - \\
\hline Escherichia coli & + & + & + & - & - & - & + & - \\
\hline Staphylococcus aureus & + & + & - & - & - & - & + & - \\
\hline Salmonella thypi & + & + & + & - & - & - & + & - \\
\hline Shigella dysenteriae & + & + & - & - & - & - & + & - \\
\hline Vibrio cholerae & + & + & + & - & - & - & + & - \\
\hline
\end{tabular}

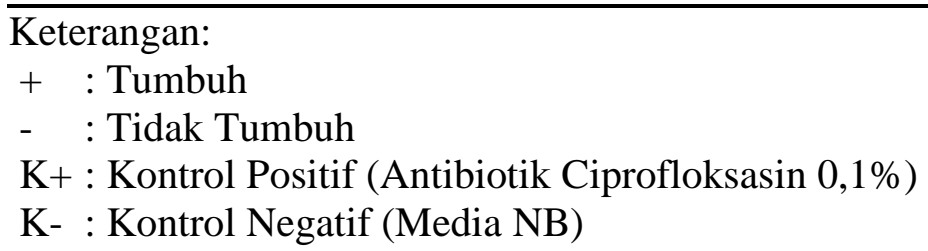

Nilai KBM pada kedua bakteri uji, baik S. aureus dan S. dysenteriae adalah $20 \%$. Hal ini diduga karena bakteri $S$. aureus dan $S$. dysenteriae tidak memiliki organ tambahan 
seperti flagel, fili, kapsul, dan spora sehingga lebih mudah untuk dibunuh. Selain itu disebabkan senyawa flavonoid ekstrak etanol daun jambu air bekerja dengan merusak membran sel bakteri Shigella dysenteriae. Sedangkan Staphylococcus aureus yang merupakan bakteri Gram positif dibunuh pada konsentrasi $20 \%$ diduga karena adanya enzim lisozim. Lisozim merupakan enzim yang berukuran relatif kecil, berbentuk monomerik yaitu terdiri dari 129 asam amino dengan BM 14600 serta dapat menghidrolisis ikatan $\beta-1,4$ Nac-N-Asetil yang melisis sel bakteri gram positif dan spektrum lisis dari lisozim hanya bekerja terhadap gram positif (Melani dkk., 2013). Enzim lisozim merupakan enzim yang sanggup mencerna dinding sel bakteri. Hilangnya dinding sel ini menyebabkan sel bekteri akan mati (Vega dkk., 2013).

\section{KESIMPULAN}

Berdasarkan hasil penelitian maka dapat disimpulkan bahwa ekstrak etanol daun jambu air mampu menghambat pertumbuhan bakteri isolat klinis. KHM tidak dapat ditentukan karena ekstrak etanol daun jambu air yang dihasilkan berwarna gelap. KBM terhadap bakteri $S$. aureus dan $S$. dysenteriae adalah 20\%. KBM terhadap E. coli, S. thypi, dan V. cholerae adalah 25\%. KBM terhadap bakteri B. cereus yaitu $50 \%$.

\section{DAFTAR PUSTAKA}

Bobbarala, V. 2012. Antimicrobial Agents. Intech, Croatia.

Cowan, M.M. 1999. Plant Products as Antimicrobial Agents. Clinical Microbiology Reviews. 12: 564 - 582.

Hariana, A. 2006. Tumbuhan Obat dan Khasiatnya. Seri Pratama. Penebar Swadaya. Jakarta.

Indrayanto, G. 2006. Prospek (Kimia) Bahan Alam untuk Penemuan Obat Baru, Seminar Umum Pendidikan Program Studi, Universitas Mulawarman.

Maliana, Y., Khotimah, S dan Diba, FS. 2013. Aktifitas Antibakteri Kulit Garcinia mangostana Linn. Terahadap Pertumbuhan Flavobacterium dan Enterobacter dari Coptotermes curvignathus Holmgren. Program Studi Biologi. Fakultas Matematika dan Ilmu Pengetahuan Alam. Universitas Tanjungpura. Pontinak. Jurnal Protabiont. 2 (1): 7-11.

Melani, D., Radiati, L. E., Thohari, I. Penambahan EDTA (ethylenediaminetetraacetic) Pada Ekstrak Lisozim Putih Telur Sebagai Antimikroba Terhadap Salmonella sp dan Staphylococcus aureus. http://fapet.ub.ac.id/wpcontent/uploads/2013/04/PENAMBAHAN-EDTA-ethylenediaminetetraacetic- 
acid-PADA-EKSTRAK-LISOZIM-PUTIH-TELUR-SEBAGAI-

ANTIMIKROBA-TERHADAP-Salmonella-sp-dan-Staphylococcus-aereus.pdf. [Diakses Senin, 24 November 2014 Pukul 23.30 WITA].

Mukherjee, K. L., 1988. Medical Laboratory Technology (A Procedur Manual for Reutine Diagnostic Test). New Delhi: Rajkamal Electric Press.

Nuria, M.C., A. Faizatun., dan Sumantri. 2009. Uji Antibakteri Ekstrak Etanol Daun Jarak Pagar ( Jatropha cuircas L) terhadap Bakteri Staphylococcus aureus ATCC 25923, Escherichia coli ATCC 25922, dan Salmonella typhi ATCC 1408. Jurnal Ilmu ilmu Pertanian. 5: 26 - 37.

Okuda, T.; Yoshida, T.; Hatano, T.; Yazaki, K.; Ashida, M. 1982. Ellagitannins of the casuarinaceae, stachyuraceae and myrtaceae. Phytochemistry. 21, 2871.

Palanisamy UD, Ling LT, Manaharan T, Sivapalan V, Subramaniam T, Helme MH, Masilamani T. 2011. Standardized extract of Syzygium aqueum : a safe cosmetic ingredient. International Journal of Cosmetic Science 33(3): 269-275.

Sari, F.P., dan S. M. Sari. 2011. Ekstraksi Zat Aktif Antimikroba dari Tanaman Yodium (Jatropha multifida Linn) sebgai Bahan Baku Alternatif Antibiotik Alami. Fakultas Teknik Universitas Diponegoro, Semarang.

Singh, I.P., S.B. Bharate. 2005. Anti-HIV Natural Products. Journal Current Science, 89 (2).

Susanti, A. 2008. Daya antibakteri ekstrak etanol daun beluntas (Pluchea indica less) terhadap Escherichia coli secara in vitro. Jurnal universitas airlangga, 1 (1).

Parwata, O. A. dan Dewi, F. S. 2008. Isolasi dan Uji Aktivitas Antibakteri Minyak Atsiri dari Rimpang Lengkuas (Alpinia galanga L.). Jurnal Kimia 2 (2): 100-104.

Thamilvaani, M., David, A., Hwee, M. C., Uma, D. P., 2012. Flavonoids Isolated from Syzygium aqueum Leaf Extract as Potential Antihyperglycaemic Agents. Food Chemistry: 132.

Vega, C., Elkana, D., Putri, O., Leonard, R., Andriyono, S., 2013. Rekayasa Chitosan Sebagai Pengawet dan Meningkatkan Kadar Protein Dalam Tahu. Jurnal Ilmiah Perikanan dan Kelautan. 5 (2).

Wong, K.C.; Lai, F.Y. 1996. Volatile constituents from fruits of four Syzygium species grown in Malaysia. Flavour Fragr. J. 11, 61-66.

World Health Organization, 2009. Medicinal Plants in Papua New Guinea. WHO Western Pasific Region. 